\title{
Characterization of Two Marker Chromosomes in a Patient with Acute Nonlymphocytic Leukemia by Two-Color Fluorescence In Situ Hybridization
}

\author{
Masafumi Taniwaki, Michael R. Speicher, Christoph Lengauer, \\ Anna Jauch, Susanne Popp, and Thomas Cremer
}

\begin{abstract}
A patient with acute nonlymphocytic leukemia (ANLL), M5b according to French-AmericanBritish (FAB) classification, showed monosomy 16, an extra 1p-, and a 21q + . These derivative chromosomes could not be defined by GTG-banding. For better characterization, we performed two-color fluorescence in situ hybridization (FISH) experiments applying DNA libraries from sorted human chromosomes, chromosome-specific repetitive probes, and a band-specific YAC-clone. With these FISH studies the karyotype could be characterized as $46, X Y,+\operatorname{der}(1) \mathrm{t}(1 ; 21)(\mathrm{p} 11 ; ?),-16, \operatorname{der}(21) t(16 ; 21)(\mathrm{p} 11.1 ; q 22)$.
\end{abstract}

\section{INTRODUCTION}

Fluorescence in situ hybridization (FISH) with DNA libraries from sorted human chromosomes and regional DNA probes has improved identification of marker chromosome [1-7]. Recently, we showed the usefulness of DNA probes generated by Alu polymerase chain reaction (PCR) of yeast artificial chromosome (YAC) clones [8] for detection of structural chromosome aberrations in patients with leukemia and myelodysplastic syndromes (MDS) at any stage of the cell cycle [9]. We describe the karyotype of a patient with acute nonlymphocytic leukemia (ANLL), M5b according to FrenchAmerican-British (FAB) classification, with an additional $1 p$ - and a $21 q$ + . GTG-banding studies did not allow accurate characterization of the two derivative chromosomes. A series of two-color FISH studies with chromosome-specific DNA libraries, centromere-specific repetitive DNA probes, and a band-specific YAC clone were performed to identify unequivocally the chromosomes that contributed to the formation of the derivatives and to localize the breakpoint regions.

\section{MATERIALS AND METHODS}

The patient was a 20-year-old man with high fever and dyspnea. Peripheral blood (PB) count showed marked leukocytosis and anemia: white blood cell (WBC) count $156 \times 10^{9 / 1}$,

From the Institut für Humangenetik und Anthropologie, Universität Heidelberg, Heidelberg, Germany.

Address reprint requests to: Masafumi Taniwaki, M.D., 3rd Department of Internal Medicine, Kyoto Prefectural University of Medicine, Kawaramachi-Hirokoji, Kamigyo-ku, Kyoto 602, Japan. Received October 29, 1992; accepted March 11, 1993. hemoglobin $6.5 \mathrm{~g} / \mathrm{dl}$. Bone marrow (BM) aspiration showed hypercellular BM with massive infiltration by blastic cells. Erythrophagocytosis was not evident. ANLL, M5b according to FAB classification, was diagnosed. The patient died of acute respiratory failure on the day of admission before chemotherapy could be initiated.

Cytogenetic analysis was performed on short-term cultures of BM cells. GTG-banding was performed before FISH [10, 11].

The following probes were used: bacteriophage DNA libraries from sorted human chromosomes 16 and 21 (LA16NSO2 and LA21NSO1) obtained from American Type Culture Collection (ATCC), plasmid library pBS1 specific for human chromosome 1 [12] provided by J. Gray (University of California, San Francisco, CA), probe pUC1.77 specific for band 1q12 [13], and probe pHUR 195 specific for 16q12 [14] provided by P. Devilee (University of Leiden, The Netherlands). YAC clone HTY 3150 provided by H. Riethman (The Wistar Institute, Philadelphia, PA) and H. Donis-Keller (Washington University, St. Louis, MO) was mapped to 16 p11.2 in our laboratory.

Human DNA sequences of the YAC clone were specifically amplified by Alu-PCR [15]. All probes were labeled by standard nick-translation using biotin-11-dUTP (Sigma) or digoxigenin-11-dUTP (Boehringer Mannheim). Two-color FISH with various probe combinations and probe detection was performed as described in detail elsewhere. Biotinylated probes were detected with avidin-FITC (Vector Laboratories), biotinylated goat antiavidin, and a second layer of avidinFITC [16]. For detection of digoxigenin-labeled probes, we used mouse anti-digoxin (Sigma), rabbit anti-mouse IgGtetramethylrhodamine (TRITC) (Boehringer Mannheim), and goat anti-rabbit IgG-TRITC (Boehringer Mannheim) [9]. Cells were counterstained with DAPI and mounted in antifade solution [17]. 


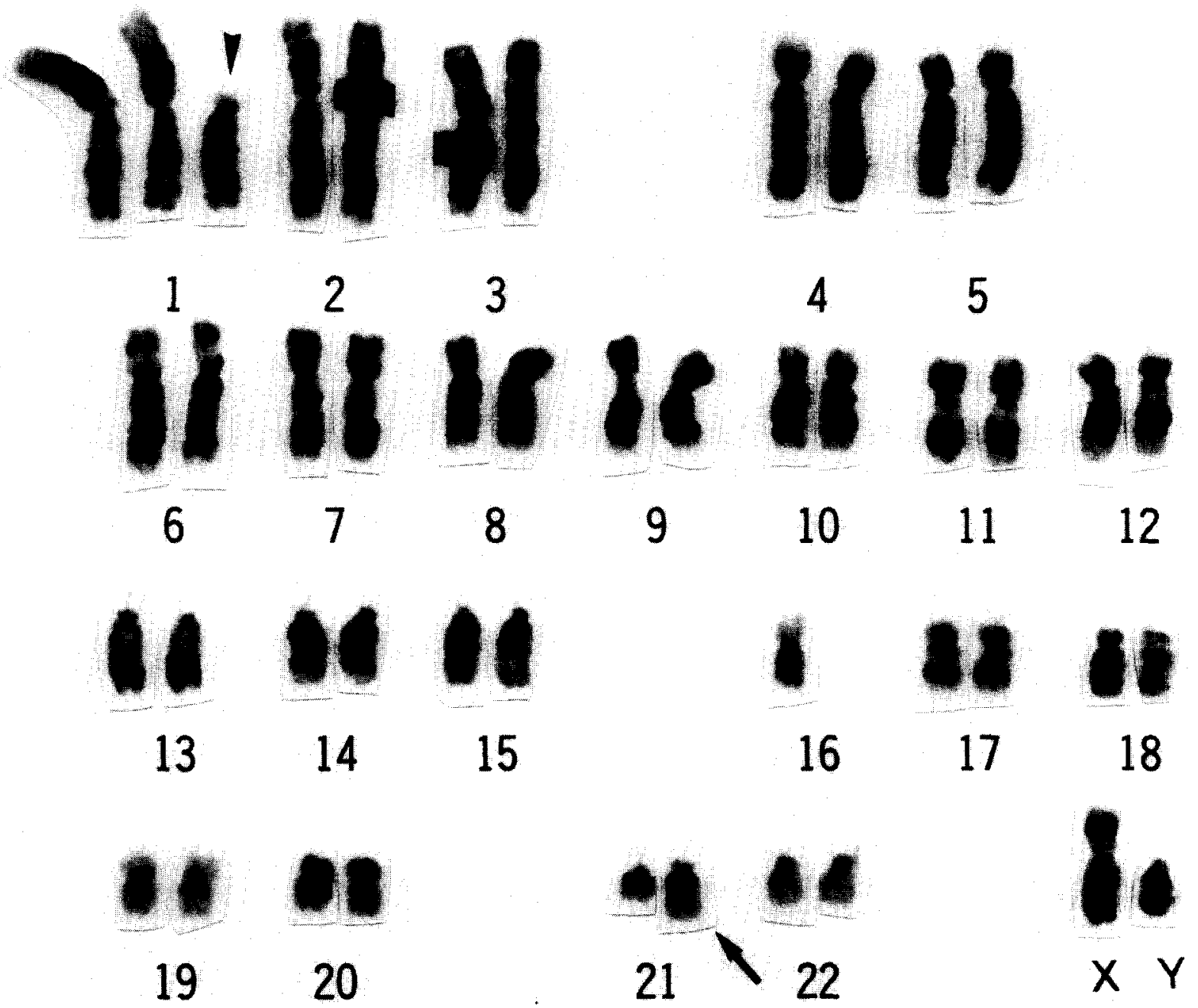

Figure 1 GTG-banded karyotype of a patient with acute nonlymphocytic leukemia. Arrowhead indicates the $1 p$ showing a pale band adjacent to $1 \mathrm{p} 11$. Arrow indicates the $21 \mathrm{q}+$.

\section{RESULTS}

Initial characterization of GTG-banded metaphase spreads showed monosomy 16 , an additional $1 p-$, and a $21 q$ + marker chromosome (Fig. 1). The origin of the added chromosome material in the $21 \mathrm{q}+$ could not be identified by banding. The 1p - marker chromosome consistently showed a pale band adjacent to $1 \mathrm{p} 11$ instead of the usual Giemsa dark band 1p12, suggesting interstitial deletion, $\operatorname{del}(1)(\mathrm{p} 11 \mathrm{p} 36.3)$, or translocation event. For further characterization of the two marker chromosomes, we performed a series of two-color FISH study. As a strategy, the chromosomal origin of extra material on the two derivative chromosomes should first be deduced by painting with a series of chromosome-specific libraries. Region-specific DNA probes should then help localize breakpoints. We decided first to identify chromosome 1 material and then to perform additional painting with chromosomespecific libraries for chromosomes 16 and 21 to clarify whether material from chromosomes 16 or 21 contributed to formation of the marker chromosome $1 \mathrm{p}$ - and whether material from chromosomes 1 or 16 participated in formation of the marker chromosome $21 \mathrm{q}+$.

Two-color FISH with chromosome 1-specific library DNA and the paracentromeric DNA probe pUC1.77 confirmed partial trisomy 1q (Fig. 2a). The pale band on the short arm of $1 \mathrm{p}-$, however, was not painted with this library (data not shown). Painting of this band was achieved in the next step using two-color FISH with chromosome 21-specific library DNA in addition to the chromosome 1-specific library DNA. This result demonstrated that the pale band adjacent to $1 \mathrm{p} 11$ on the $1 \mathrm{p}$ - was the result of translocated chromosome 21 material. Although we could not define the band of chromosome 21 involved in this translocation, the results show a complex translocation involving chromosomes 1,16 , and 21 (Fig. 2b).

For further characterization of $21 \mathrm{q}+$, a two-color FISH study with chromosome-specific library DNA for chromo- 

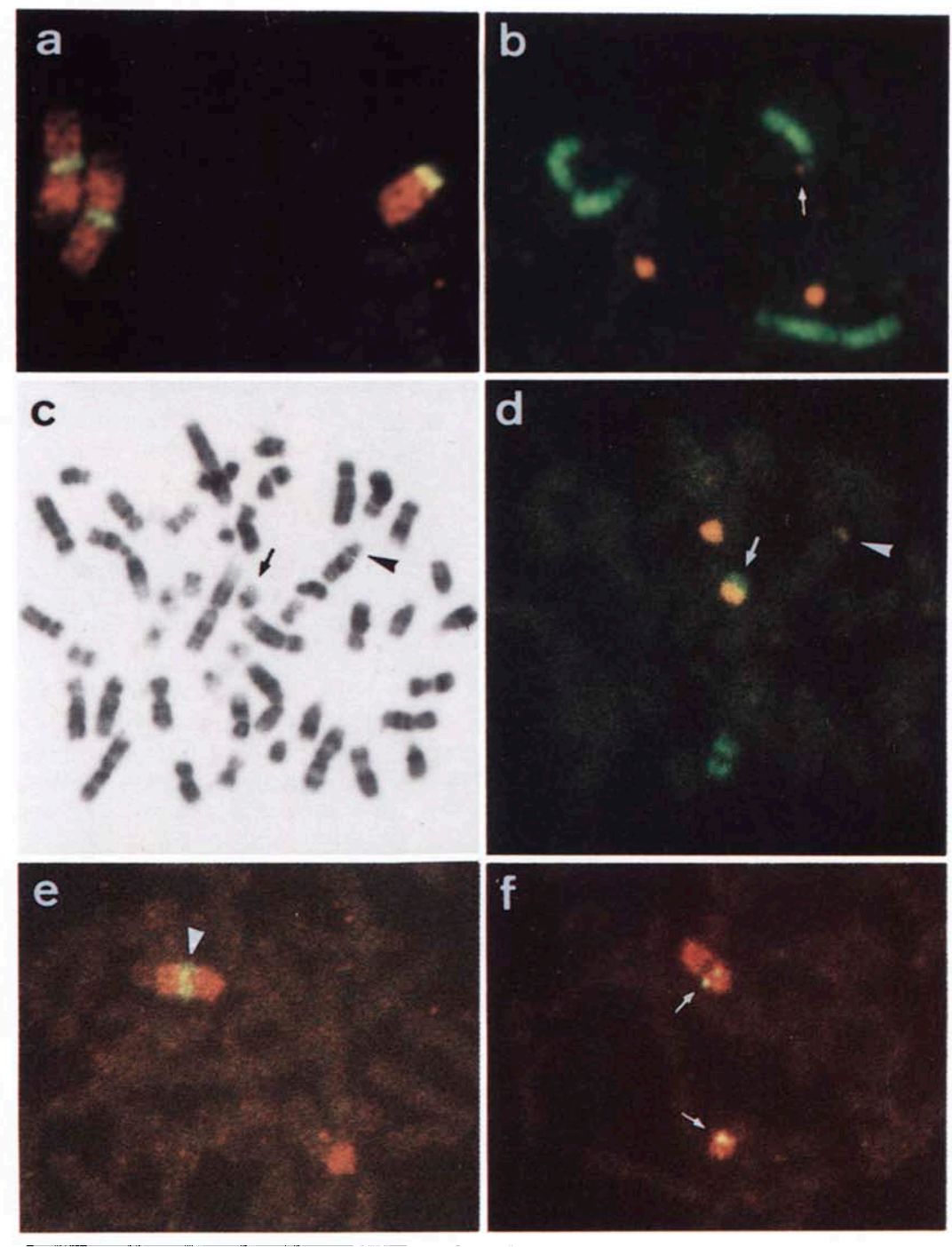

Figure 2 Fluorescence in situ hybridization (FISH) to leukemic cells of the patient with acute nonlymphocytic leukemia (ANLL) (Fig. 1). Biotinylated DNA probes were detected with avidin-FITC (green), DNA probes labeled with digoxigenin were detected with IgG-tetramethylrhodamine (TRITC)-conjugated antibodies (red). (a) Two-color FISH with chromosome 1-specific library DNA (red) and the 1q12 specific probe pUC1.77 (green). Partial metaphase spread shows two normal and one derivative chromosome 1. All painted chromosomes show green signals at the 1q12. (b) Metaphase spread after two-color FISH with chromosome 1-specific (green) and chromosome 21-specific library DNAs (red). Partial metaphase spread shows the painted two normal chromosomes 1 and 21. Arrow indicates translocation of chromosome 21 material to $1 \mathrm{p}$. GTG-banded metaphase spread (c) subsequently painted by two color FISH with chromosome 16-specific (green) and chromosome 21-specific (red) library DNAs (d). Arrow indicates chromosome 16 material translocated to 21q. Arrowhead points to chromosome 21 material translocated to 1p. In addition, a normal chromosome 16 and 21, respectively, is painted. (e) Partial metaphase spread after two-color FISH with chromosome 16-specific library DNA (red) and the 16q12-specific DNA probe pUHR195 (green). Arrowhead indicates a normal chromosome 16 carrying a centromere-specific signal. The painted chromosome 16 -derived material in the $21 \mathrm{q}+\mathrm{shows}$ no hybridization signal with probe pUHR195. (f) Partial metaphase spread after two-color FISH with chromosome 16-specific library DNA (red) and the YAC clone HTY3150 specific for band 16p11.2 (green). Both the normal chromosome 16 and the chromosome 16-derived material in the $21 \mathrm{q}+$ are painted and show hybridization signals of the YAC clone (arrows).

somes 16 and 21 was performed on GTG-banded metaphase spreads. The chromosome 16-specific library DNA painted the distal part of the long arm of the derivative chromosome 21 (Fig. 2c and d). To define further the translocated chromosome 16 material, probe pHUR 195 specific for $16 q 12$ was used in combination with the chromosome 16-specific li- brary DNA. A paracentromeric signal was observed only on the normal chromosome 16 , but not on the $21 \mathrm{q}+$ marker chromosome (Fig. 2e). To define which arm of chromosome 16 was involved in the translocation, two-color FISH was performed with chromosome 16-specific library DNA in combination with a YAC clone mapping to band 16p11.2. In this 
experiment, the YAC signal was observed on the chromosome 16-derived region on the $21 \mathrm{q}+$ (Fig. 2f). These results not only demonstrated the involvement of $16 \mathrm{p}$ material in the $21 q+$ but also narrowed down the breakpoint to 16cen-p11.2 . Based on the additional data obtained by FISH, the karyotype was defined as $46, \mathrm{XY},+\operatorname{der}(1) \mathrm{t}(1 ; 21)(\mathrm{p} 11 ; ?),-16, \operatorname{der}(21)$ $\mathrm{t}(16 ; 21)(\mathrm{p} 11.1 ; \mathrm{q} 22)$.

\section{DISCUSSION}

In the present study, we demonstrate the potential of twocolor FISH studies using chromosome-specific DNA libraries in combination with regional-specific DNA probes for unequivocal assignment of chromosome material in two marker chromosomes from a patient with ANLL, M5b. Because a $t(16 ; 21)(p 11 ; q 22)$ has been reported in several patients with ANLL [18], the complex translocation involving chromosomes 1,16 , and 21 in the present patient represents a variant $\mathrm{t}(16 ; 21)$.

Multiple-color FISH approaches are presently being developed using combinations of three or even more fluorochromes to label chromosome-specific library probes and regional probes, such as centromere-specific repetitive DNA probes or band-specific YAC probes [19]. FISH with YAC clones spanning breakpoint regions of interest appear ideally suited for detection of specific translocations in tumor cells at any stage of the cell cycle [9, 20, 21]. These developments make possible new strategies to identify the origin of translocated materials in marker chromosomes rapidly in cases in which chromosome banding analyses do not provide unequivocal results. In comparison to chromosome banding analyses, FISH has the additional advantages that chromosome spreads with poor morphology, a common occurrence in patients with leukemia, can be included.

The authors thank Harold Riethman (The Wister Institute, Philadelphia, PA) and Helen Donis-Keller (Washington University, St. Louis, MO) for providing YAC clone HTY3150, Kazuhiro Nishida for providing samples from the patient with ANLL, B. Schoell for expert technical assistance, and A. Wiegenstein for photographic work. This work was supported by a grant from Deutsche Krebshilfe (W23/90/ Cr1). M.T. was the recipient of a fellowship from the Alexander-vonHumboldt-Stiftung.

\section{REFERENCES}

1. Cremer T, Tesin D, Hopman AHN, Manuelidis L (1988): Rapid interphase and metaphase assessment of specific chromosomal changes in neuroectodermal tumor cells by in situ hybridization with chemically modified DNA probes. Exp Cell Res 176:199-220.8.

2. Smit VTHBM, Wessels JW, Mollevanger P, Schrier PI, Raap AM, Beverstock GC, Cornelisse CJ (1990): Combined GTG-banding and nonradioactive in situ hybridization improves characterization of complex karyotypes. Cytogenet Cell Genet 54:20-23.

3. Speleman F, Mangelschots K, Vercruyssen M, Dal Cin P, Aventin A, Offner F, Laureys G, Van den Berghe, Leroy J (1991): Analysis of whole-arm translocations in malignant blood cells by nonisotopic in situ hybridization. Cytogenet Cell Genet 56:14-17.

4. Pinkel D, Landegent J, Collins C, Fusco J, Segraves R, Lucas J, Gray JW (1988): Fluorescence in situ hybridization with human chromosome specific libraries: Detection of trisomy 21 and translocation of chromosome 4. Proc Natl Acad Sci USA 85:9138-9142.

5. Lichter P, Cremer T, Borden J, Manuelidis L, Ward DC (1988): Delineation of individual human chromosomes in metaphase and interphase cells by in situ suppression hybridization using recombinant DNA libraries. Hum Genet 80:224-234.

6. Cremer T, Lichter P, Borden J, Ward DC, Manuelidis L (1988): Detection of chromosome aberrations in metaphase and interphase tumor cells by in situ hybridization using chromosomespecific library probes. Human Genet Hum Genet 80:235-246.

7. Brothman AR, Patel AM (1992): Characterization of 10 marker chromosomes in a prostatic cancer cell line by in situ hybridization. Cytogenet Cell Genet 60:8-11.

8. Burke DT, Carle GF, Olson MV (1987): Cloning of large segments of exogeneous DNA into yeast by means of artificial chromosome vectors. Science 236:806-812.

9. Lengauer C, Riethman HC, Speicher MR, Taniwaki M, Konecki D, Green ED, Becher R, Olson MV, Cremer T (1992): Metaphase and interphase cytogenetics with Alu-PCR amplified YAC clones containing the BCR-gene and the protooncogenes $\mathrm{c}-\mathrm{raf}-1, \mathrm{c}-\mathrm{fms}$, c-erbB-2. Cancer Res 52:2590-2596.

10. Klever M, Grond-Ginsbach C, Scherthan H, Schroeder-Kurth $T$ (1991): Chromosomal in situ suppression hybridization after Giemsa banding. Hum Genet 86:484-486.

11. Lichter P, Cremer T (1992): Chromosome analysis by nonisotopic in situ hybridization. In: Human Cytogenetics - A Practical Appraach, 2nd ed. vol. I, DE Rooney, BH Czepulkowski, eds. IRL Press, Oxford, pp. 157-192.

12. Collins C, Kuo WL, Segraves R, Fuscoe J, Pinkel D, Gray JW (1991): Construction and characterization of plasmid libraries enriched in sequences from single human chromosomes. Genomics. 11:997-1006.

13. Cooke HJ, Hindley J (1979): Cloning of human satellite III DNA: Different components are on different chromosomes. Nucleic Acid Res 6:3177-3197.

14. Moyzis RK, Albright KL, Bartholdi MF, Cram LS, Deaven LL, Hildebrand CE, Joste NE, Longmire JL, Meyne J, SchwarzacherRobinson T (1987): Human chromosome-specific repetitive DNA sequences: Novel markers for genetic analysis. Chromosome 95:375-386.

15. Lengauer C, Green ED, Cremer T (1992): Fluorescence in situ hybridization of YAC clones after inter-Alu-PCR amplification. Genomics 13:826-828.

16. Pinkel D, Straume T, Gray JW (1986): Cytogenetic analysis using quantitative, high sensitivity, fluorescence hybridization. Proc Natl Acad Sci USA 83:2934-2938.

17. Jauch A, Daumer C, Lichter P, Murken J, Schroeder Kurth T, Cremer T (1990): Chromosomal in situ suppression hybridization of human gonosomes and autosomes and its use in clinical cytogenetics. Hum Genet 85:145-150.

18. Marosi C, Bettelheim P, Geissler K, Lechner K, Koeller U, Haas OA, Chott A, Hagemeijer A (1991): Translocation (16;21)(p11;q22) in acute monoblastic leukemia with erythrophagocytosis. Cancer Genet Cytogenet 54:61-66.

19. Lengauer C, Speicher MR, Popp S, Jauch A, Taniwaki M, Nagaraja R, Riethman HC, Donis-Keller H, D'Urso M, Schlessinger D, Cremer T (1992): Chromosomal bar codes constructed by multicolor fluorescence in situ hybridization with ALU-PCR products of multiple YAC clones. (in press).

20. Rowley JD, Diaz MO, Espinosa III R, Patel JD, van Melle E, Ziemin S, Taillon-Miller P, Lichter P, Evans GA, Kersey JH, Ward DC, Domer PH, Le Beau MM (1990): Mapping chromosome band 11q23 in human acute leukemia with biotinylated probes: Identification of $11 \mathrm{q} 23$ translocation breakpoints with a yeast artificial chromosome. Proc Natl Acad Sci USA 87:9358-9362.

21. Selleri L, Hermanson GG, Eubanks JH, Evans GA (1991): Chromosomal in situ hybridization using yeast artificial chromosomes. Genet Anal Techn Appl 8:59-66. 